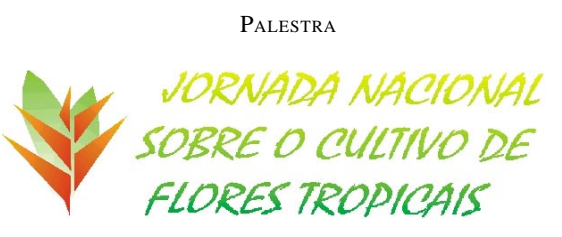

\title{
Diagnóstico do mercado de flores tropicais
}

\section{ROGÉRIO MATIELLO VERA ${ }^{(1)}$}

A oferta e comercialização de Flores Tropicais no Mercado de Flores da CEASA - Campinas são ainda incipientes diante do potencial que a flor possui em decorações.

Atualmente o mercado é atendido pelas regiões produtoras do Rio de Janeiro, sul da Bahia e Atibaia, além também de alguns atacadistas abastecidos por outros importantes Centros de Comercialização de Flores.

No mês de outubro de 2007, foi realizado junto aos compradores do Mercado de Flores da CEASA Campinas uma enquete referente ao comércio de FLORES TROPICAIS.

Tais informações não possuem cunho científico, por não ter sido utilizado amostra probabilística ou tratamento estatístico, contudo nos possibilitaram contribuir na aquisição de conhecimento, compreendendo e interpretando os fenômenos presentes na transação comercial das Flores Tropicais.

Foram utilizadas no questionário perguntas, cujas alternativas de resposta possuíam valores opostos, como "sim" e "não", além também de questões abertas e semi-abertas, em que o entrevistado justificava a resposta dada.

O levantamento teve como objetivos:

A - levantar opiniões referentes aos produtos que pertence ao grupo de Flores Tropicais;

B - alcançar uma compreensão qualitativa das razões e motivações envolvidas na compra do produto;

$\mathrm{C}$ - permitir um entendimento do (s) "por quês(s)" da referida questão.

O perfil dos entrevistados nessa enquete sobre o comércio de Flores Tropicais, segundo o segmento da atividade estava dividido em atacadistas com 7,8\%, decoradores com 30,70\% e Floriculturas com 61,50\%.

A distribuição regional dos entrevistados está representada por importantes Estados compradores (tabela 1), contudo estes participaram da enquete de forma voluntária.
Com relação às compras de Flores Tropicais, $46,15 \%$ dos entrevistados declararam que adquirem tais produtos de forma regular, em contrapartida-partida 53,85\% afirmam não efetuar compras com freqüência.

As respostas quanto à freqüência de compras de Flores Tropicais estão distribuídas; como todo dia de comercialização (segunda e quinta-feira) com 16,67\%, semanal (pelo menos uma vez) com 33,33\%, quinzenal $(33,33 \%)$ e mensal $(16,67 \%)$

Quando perguntado aos entrevistados qual a época do ano de maior consumo, houve múltiplas respostas e as mais mencionadas foram:

- no período de festas temáticas (meses de novembro e dezembro);

- compra esporádica e/ou pedido do cliente;

. toda semana;

- semanal.

Verificou-se uma demanda reduzida para as Flores Tropicais, com vendas irregulares, com forte dependência de pedidos do consumidor final e decorações temáticas como as "Festas do Havaí" e Reveillon que ocorrem nos meses de novembro e dezembro.

Com relação as principais motivações para a compra de Flores Tropicais, a durabilidade da flor foi a resposta mais mencionada, seguida do apelo exótico do produto, a forte demanda para a flor para as Festas Temáticas, além da beleza e do calor visual nos arranjos e decorações, bem como procura do cliente pela produto.

A durabilidade da flor é o atributo mais solidificado por parte dos entrevistados, possibilitando definir um nicho de mercado que é a utilização das flores tropicais no segmento de clientes institucionais como empresas, por intermédio de "assinatura de flores", como assim denominam as floriculturas e ainda poderiam focar o produto nas empresas de organização e realização de eventos em locais adaptados ou itinerantes não muito adequados às flores temperadas devido ao excessivo calor.

Tabela 1. Distribuição regional dos entrevistados na CEASA

\begin{tabular}{|c|c|}
\hline Região - UF & Participacão (\%) \\
\hline $\mathrm{RS}$ & 7,80 \\
\hline GO & 7,80 \\
\hline MG & 15,60 \\
\hline $\mathrm{SP}$ & 68.80 \\
\hline
\end{tabular}

\footnotetext{
${ }^{(1)}$ Engenheiro Agrônomo, Departamento do Mercado de Flores, CEASA - Campinas. E-mail: flores@ceasacampinas.com.br
} 
Dos compradores entrevistados, 69,23\% entendem que se tivesse mais procura por parte dos clientes, estes utilizariam mais flores, já 30,77\% não comprariam mais flores, cujas razões negativas e justificadas foram a reduzida demanda pelo produto e seu odor desagradável. Entende-se que o consumidor final necessita de informações do produto a fim de atender às necessidades próprias e promover aumento de consumo, contudo ficou evidente que os profissionais da área não tem o domínio das características positivas da flor, com exceção da durabilidade. Diante de tal situação não existe uma boa perspectiva no processo de transferência de informação para o consumidor.

Quanto aos atributos relacionados capazes de influenciar a decisão de compra, com múltiplas respostas mencionadas pelos entrevistados por ordem decrescente, podem-se destacar:

. qualidade de produto;

. escolha/pedido do cliente;

. custo mais baixo do produto;

. beleza e oferta do produto.
Nessa questão das influências envolvidas na decisão de compra constatou-se surpresa, pois a beleza intrínseca da flor não foi o atributo mencionado de maior peso, e sim a qualidade, portanto o produtor possui uma tarefa crítica no sentido de produzir com qualidade e manter essa qualidade até o ponto de venda, utilizando técnicas de pós-colheita adequada.

É notório que as flores possuem baixa rejeição de compra pelos compradores, contudo contatouse na enquete que $23,0 \%$ possuem objeções de compra, em que a baixa qualidade do produto, custo elevado da flor e odor desagradável são os fatores que inibem as vendas.

Ficou evidente a preocupação dos compradores quanto à qualidade da flor, portanto faz-se necessária a devida capacitação do produtor na adequação do ponto colheita da flor, limpeza, e tratamentos de póscolheita. 